\title{
Estimation of biomass and carbon stocks: the case of the Atlantic Forest
}

\author{
Simone Aparecida Vieira ${ }^{1}$, Luciana Ferreira Alves' ${ }^{2}$ Marcos Aidar $^{2}$, Luciana Spinelli Araújo ${ }^{3}$, \\ Tim Baker, João Luís Ferreira Batista², Mariana Cruz Campos ${ }^{5}$, Plinio Barbosa Camargo ${ }^{1}$, \\ Jerome Chave, Welington Braz Carvalho Delitti ${ }^{7}$, Niro Higuchi ${ }^{8}$, Euridice Honorio',
}

Carlos Alfredo Joly, Michael Keller ${ }^{1,10,11}$, Luiz Antonio Martinelli', Eduardo Arcoverde de Mattos ${ }^{12}$,

Thiago Metzker ${ }^{13}$, Oliver Phillips ${ }^{4}$, Flavio Antonio Maes dos Santos ${ }^{5}$, Mônica Takako Shimabukuro ${ }^{14}$,

Marcos Silveira $^{15}$ \& Susan Elizabeth Trumbore ${ }^{16}$

${ }^{1}$ Laboratório de Ecologia Isotópica, Centro de Energia Nuclear na Agricultura - CENA, Universidade de São Paulo - USP, Av. Centenário, 303, Piracicaba, SP, Brazil

${ }^{2}$ Seção de Ecologia, Instituto de Botânica de São Paulo - IBt-SP

${ }^{3}$ Laboratório de Ecologia e Restauração Florestal,

Escola Superior de Agricultura “Luiz de Queiroz” Esalq

${ }^{4}$ School of Geography, University of Leeds, UK

${ }^{5}$ Instituto de Biologia, Universidade de Campinas - UNICAMP

${ }^{6}$ Centre National de la Recherche Scientifique, Université Paul Sabatier, Toulouse, France

${ }^{7}$ Instituto de Biociências, Universidade de São Paulo - USP

${ }^{8}$ Departamento de Silvicultura Tropical e Manejo Florestal, Instituto Nacional de Pesquisas da Amazônia - INPA

${ }^{9}$ Instituto de Investigaciones de la Amazonía Peruana

${ }^{10}$ International Institute of Tropical Forestry, Forest Service,

United States Department of Agriculture - USDA

${ }^{11}$ Complex Systems Research Center,University of New Hampshire, USA

${ }^{12}$ Laboratório de Ecologia Vegetal, Departamento de Ecologia, Instituto de Biologia - IB, CCS, Universidade Federal do Rio de Janeiro - UFRJ

${ }^{13}$ Departamento de Botânica, Instituto de Ciências Biológicas, Universidade Federal de Minas Gerais - UFMG

${ }^{14}$ Divisão de Sensoriamento Remoto, Instituto Nacional de Pesquisas Espaciais - INPE

${ }^{15}$ Centro de Ciências Biológicas e da Natureza, Universidade Federal do Acre - UFAC

${ }^{16}$ Institute for Geophysics and Planetary Physics, University of California, USA

${ }^{17}$ Corresponding Author: Simone Aparecida Vieira, e-mail: savieira@cena.usp.br

VIEIRA, S.A., ALVES, L.F., AIDAR, M.P.M., ARAÚJO, L.S., BAKER, T., BATISTA, J.L.F., CAMPOS, M.C.R., CAMARGO, P.B., CHAVE, J., DELITTI, W.B., HIGUCHI, N., HONÓRIO, E., JOLY, C.A., KELLER, M., MARTINELLI, L.A., DE MATTOS, E.A., METZKER, T., PHILLIPS, O., SANTOS, F.A.M., SHIMABUKURO, M.T., SILVEIRA, M. \& TRUMBORE, S.E. 2008. Estimation of biomass and carbon stocks: the case of the Atlantic Forest. Biota Neotrop. 8(2): http://www.biotaneotropica.org.br/v8n2/en/abstract?point-ofview+bn00108022008.

Abstract: The main objective of this paper is to present and discuss the best methods to estimate live above ground biomass in the Atlantic Forest. The methods presented and conclusions are the products of a workshop entitled "Estimation of Biomass and Carbon Stocks: the Case of Atlantic Rain Forest".

Aboveground biomass (AGB) in tropical forests is mainly contained in trees. Tree biomass is a function of wood volume, obtained from the diameter and height, architecture and wood density (dry weight per unit volume of fresh wood). It can be quantified by the direct (destructive) or indirect method where the biomass quantification is estimated using mathematical models. The allometric model can be site specific when elaborated to a particular ecosystem or general that can be used in different sites.

For the Atlantic Forest, despite the importance of it, there are only two direct measurements of tree biomass, resulting in allometric models specific for this ecosystem.

To select one or other of the available models in the literature to estimate AGB it is necessary take into account what is the main question to be answered and the ease with which it is possible to measure the independent variables in the model. Models that present more accurate estimates should be preferred. However, more simple models (those with one independent variable, usually DBH) can be used when the focus is monitoring the variation in carbon storage through the time.

Our observations in the Atlantic Forest suggest that pan-tropical relations proposed by Chave et al. (2005) can be confidently used to estimated tree biomass across biomes as long as tree diameter (DBH), height, and wood density are accounted for in the model. 
Vieira, S.A. et al

In Atlantic Forest, we recommend the quantification of biomass of lianas, bamboo, palms, tree ferns and epiphytes, which are an important component in this ecosystem.

This paper is an outcome of the workshop entitled "Estimation of Biomass and Carbon Stocks: the Case of Atlantic Rain Forest", that was conducted at Ubatuba, São Paulo, Brazil, between 4 and 8 December 2006 as part of the Brazilian project "Ombrophylus Dense Forest floristic composition, structure and function at the Núcleos Picinguaba and Santa Virginia of the Serra do Mar State Park", BIOTA Gradiente.

Keywords: Atlantic Forest, above-ground biomass, allometric model, carbon, Mata Atlântica.

VIEIRA, S.A., ALVES, L.F., AIDAR, M.P.M., ARAÚJO, L.S., BAKER, T., BATISTA, J.L.F., CAMPOS, M.C.R., CAMARGO, P.B., CHAVE, J., DELITTI, W.B., HIGUCHI, N., HONÓRIO, E., JOLY, C.A., KELLER, M., MARTINELLI, L.A., DE MATTOS, E.A., METZKER, T., PHILLIPS, O., SANTOS, F.A.M., SHIMABUKURO, M.T., SILVEIRA, M. \& TRUMBORE, S.E. 2008. Estimativas de biomassa e estoque de carbono: o caso da Mata Atlântica. Biota Neotrop. 8(2): http://www.biotaneotropica.org.br/v8n2/pt/abstract?point-ofview+bn00108022008.

Resumo: O principal objetivo deste artigo é apresentar e discutir a melhor forma para estimar a biomassa viva acima do solo (BVS) na Mata Atlântica.

A biomassa viva acima do solo em florestas tropicais esta contida principalmente nas árvores. A biomassa das árvores é uma função do seu volume de madeira, obtido do diâmetro e da altura, de sua arquitetura e da densidade de sua madeira (peso seco por unidade de volume fresco). Ela pode ser quantificada pelo método direto (destrutivo) ou pelo método indireto onde a quantificação da biomassa é feita através de modelos matemáticos. Os modelos alométricos podem ser específicos para um determinado local, quando elaborado para um ecossistema particular, ou gerais, que podem ser utilizados em para estimar a biomassa em diferentes locais.

Para a Mata Atlântica, a despeito de sua importância, existem somente duas medidas diretas de biomassa de árvores, que resultaram em modelos alométricos específicos para essas florestas.

Para selecionar um ou outro modelo alométrico para estimar BVS, disponível na literatura, é necessário levar em conta o a questão a ser respondida e a facilidade com a qual é possível medir as variáveis independentes do modelo. Preferencialmente, deve-se utilizar modelos que apresentem estimativas mais acuradas, entretanto modelos mais simples (aqueles com apenas uma variável independente, normalmente o DAP) podem ser utilizados quando o foco for o monitoramento das variação no estoque de carbono através do tempo.

Observações para a Mata Atlântica sugerem que o modelo pan-tropical proposto por Chave et al. (2005) podem ser utilizadas com confiança entre os biomas, uma vez que o mesmo engloba o DAP a altura e a densidade da madeira.

Na Mata Atlântica, onde as lianas, bambus, palmeiras, fetos arborescentes e epífitas são um importante componente do sistema, recomenda-se a quantificação dos mesmos.

Este artigo é o resultado do workshop "Estimativa da biomassa e estoques de carbono: o processo de Mata Atlântica”, realizado em Ubatuba, São Paulo, Brasil, entre 4 e 8 de Dezembro de 2006 como parte do projeto temático BIOTA/FAPESP "Composição florística, estrutura e funcionamento da Floresta Ombrófila Densa dos Núcleos Picinguaba e Santa Virgínia do Parque Estadual da Serra do Mar”, BIOTA Gradiente.

Palavras-chave: Mata Atlântica, biomassa acima do solo, modelo alométrico, carbono. 


\section{Introduction}

The Brazilian Atlantic Forest (locally called the Mata Atlântica and hereafter referred as Atlantic Forest) is considered a hot-spot in terms of biodiversity and endemism (Myers et al. 2000). The Atlantic Forest is a mosaic of ecosystems that belongs to the Atlantic Dominion (IBGE 1992, Joly et al. 1999). Dense tropical rain forest predominates and includes areas of coastal flooded forest (restinga), lowland, submontane and montane forests. Before the European colonization, the Atlantic Forest covered the Brazilian coast from Cabo de São Roque, Rio Grande do Norte to Osorio municipality, Rio Grande do Sul. However, after 500 years of fragmentation and degradation, the steepest slope areas near the Atlantic coast are about all that has survived as forests because of the difficulty of cultivating those areas. Only about $8 \%$ of the original forest cover remains (Hirota 2003) and the forest remnants (often distributed in small and degraded fragments) are inserted into a matrix altered by human activities.

In the last three decades many studies have been conducted in the Atlantic Forest, the majority related to the diversity of its fauna and flora (Leitão Filho 1993, Torezan 1995, Morellato \& Haddad 2000, Oliveira Filho \& Fontes 2000). However, relatively little information is available about the structure and functioning of this ecosystem (Domingos et al. 1998, Moraes et al. 1999, Villela et al. 2006). In order to put conservation, management, and restoration of the Atlantic Forest on a strong scientific foundation, more research is urgently needed to help understand the mechanisms regulating the biodiversity, as well as the processes controlling the structure and function of these forests.

Tropical forests are large carbon reservoirs (Malhi et al. 1999), hence research on the structure and function of these biomes is relevant to the global carbon cycle. While the current extent of the Atlantic Forest is small, it once covered 1.36 million $\mathrm{km}^{2}$ and therefore may have contained as much as 7-14 Pg C. Most of the carbon stock of the Atlantic Forest was removed in the last 150 years (Dean 1995). Past, present and potential future carbon stocks (including regeneration) of the Atlantic Forest are thus relevant to global $\mathrm{C}$ budgets.

The estimation of the current carbon stocks in the Atlantic Forest depends on knowledge of dry aboveground biomass (AGB). The AGB of forests has been determined mainly by extrapolation of plot measurements of forest structural variables, principally diameter, height, and wood density of trees, based on allometric equations that convert the structural variables into biomass and carbon (Brown 1997, Chave et al. 2005). The AGB in forests is mainly contained in trees and despite the biological importance of the Atlantic Forest, there are only two direct measurements of tree mass for the dense tropical forest developed by harvest and direct weighing. One study is from the Santos foothills (Burger 2005) and the other from the region of Guaraqueçaba, located about $140 \mathrm{~km}$ from Curitiba (Tiepolo et al. 2002). As will be discussed below, this sampling has some limitations. It would be desirable to expand the number of direct measurements of tree mass, however most fragments of the Atlantic Forest are located in protected areas; hence the development of allometric models using destructive methods is impracticable.

In this paper, we explore the possibility of using existing tropical forest allometric models for the Atlantic Forest in the State of São Paulo. Our objective is to evaluate methodologies for estimation of AGB that could be used for São Paulo state and the entire Atlantic Forest biome.

\section{Background}

Tropical forests have motivated a worldwide interest because the reduction in forest extent contributes about $20 \%$ of the current atmospheric increase in $\mathrm{CO}_{2}$ concentration (Houghton \& Hackler 2006, Ramankutty et al. 2007). The Amazon forest has received special attention because it is one of the largest carbon reservoirs in the world and it offers great potential for carbon trading, generating income, and enhancing biodiversity conservation in Amazonian countries (e.g. Santilli et al. 2005), but it is also potentially at risk from climate change during this century (e.g. Betts 2006). Alterations in the carbon storage in the soil and vegetation, as a consequence of land use change, can strongly influence the emissions and fixation of carbon in these ecosystems (Jackson et al. 2001, Jandl et al. 2007).

Recent studies suggest that the carbon storage in undisturbed tropical forests is increasing (Phillips et al. 1998, Phillips et al. 2002, Baker et al. 2004b) although the question remains controversial (e.g. Rice et al. 2004, Feeley et al. 2007). Long term monitoring of permanent plots of tropical forests has also indicated an increase in tree mortality and recruitment rates ("turnover") in recent decades (Phillips \& Gentry 1994, Lewis et al. 2004, Venkateswaran \& Parthasarathy 2005). In the Neotropics, the basal area and the biomass of mature forests have increased during the same period (Phillips et al. 1998). The net uptake of atmospheric $\mathrm{CO}_{2}$ may be as large as 0.5-1.0 $\mathrm{Pg} \mathrm{C}$ per year in mature neotropical forests, similar in magnitude to the fossil fuel emissions of the European community.

\section{Allometric Models}

Tree biomass is a function of wood volume (obtained from the diameter and height), architecture and wood density (dry weight per unit volume of fresh wood). Density varies according to species (Sterck et al. 2001, Swaine \& Whitmore 1988), tree age (Fujimoto et al. 2006), life-history strategy (King et al. 2005), and environmental factors such as topography and slope aspect (Hultine et al. 2005). Tree biomass can be quantified by either destructive harvest (direct method) or allometric equations (indirect method) that are ultimately based on harvested trees (Brown 1997, Chave et al. 2005). Allometric models relate tree dry mass (obtained by the direct method) to measurable variables such as DBH (diameter at breast height), total tree height, and wood density (Brown et al. 1989, King 1996, Abdala et al. 1998, Delitti et al. 2006). Most studies of biomass employ allometric models to quantify ABG because harvest and weighing trees is destructive and expensive.

Although allometric modeling has been used since the development of regression analyses in the first half of $20^{\text {th }}$ century (Machado \& Figueiredo 2003), only a few allometric models are available to estimate AGB of tropical forests (Cole \& Ewel 2006). While the methodology to build models has advanced owing to the accessibility of computers (Curtis 1967, Loetsch \& Haller 1973, Wirth et al. 2004, Pili et al. 2006), it is difficult to develop a general allometric model for tropical trees. For tropical forests, most models have been developed using data from equatorial areas (Dawkins 1961, Brown et al. 1989, Overman et al. 1994, Brown 1997, Araújo et al. 1999, Chambers et al. 2001, Ketterings et al. 2001).

Chave et al. (2005) used data from 28 sites in tropical forests across a wide latitudinal range $\left(12^{\circ} \mathrm{S}\right.$ to $\left.25^{\circ} \mathrm{N}\right)$ to develop a pantropical allometric models for tree mass based on $\mathrm{DBH}$, total height, and wood density (Table 1). The models were separated by dry, moist and wet forests according to the Holdridge Life-Zone classification (Holdridge et al. 1971). For each of these forest types, models were proposed based on either one, two or three independent variables: 1) $\mathrm{DBH}$ or basal diameter; 2) $\mathrm{DBH}$ and wood density; and 3) $\mathrm{DBH}$, wood density and total height.

For the Atlantic Forest there are only two site-specific allometric models to predict tree mass, based on direct measures of harvested trees. The first uses DBH as an independent variable and was developed from trees harvested in a forest near Guaraqueçaba, Paraná State (Tiepolo et al. 2002). The second model (Burger 2005) used tree basal diameter and height data sampled in a forest near Santos, 
São Paulo State. Because this model used basal diameter (maximum only $47.5 \mathrm{~cm}$ ) as opposed to DBH, it cannot be applied accurately to most forest inventories but the author developed another model using DBH to make it more useful that will be available soon in an upcoming article.

While most allometric models for biomass in tropical forests are based solely on DBH (Table 1) (Chambers et al. 2001, Tiepolo et al. 2002, Chave et al. 2005), tree height should be considered because it varies with relief, soil type and tree life history (Chave et al. 2005). Most of the inventories do not include tree height because it is time consuming to measure accurately in the field, and if used accurate measures are needed. As an example, taking a stem with a DBH of $20 \mathrm{~cm}$ and $13 \mathrm{~m}$ height and using Chave et al. (2005) and Scatena et al. (1993) models the estimated AGB was 153.0 and 127.0 Kg, respectively. Keeping the same DBH but increasing the estimated height by one meter, AGB estimates become 164.1 and $136.6 \mathrm{Kg}$, respectively, an increase of around $7 \%$ and $5 \%$ in the estimated AGB.

Mean tree height in Western Amazon forests (Vieira et al. 2004) is greater than the mean tree height in the Atlantic forest for similar DBH (Figure 1). Based on this comparison, we expect that estimation of tree mass for the Atlantic Forest using models based on DBH developed for the Amazon Forest would lead to overestimation of Atlantic Forest tree mass.

Table 1. Allometric models to estimate dry aboveground biomass ( $\mathrm{kg}$ ) for tropical forests. Biomass regression models may include trunk diameter DBH (in cm) and total tree height $\mathrm{H}$ (in $\mathrm{m}$ ) and wood specific gravity " $\rho$ " (in g. $\mathrm{cm}^{3}$ ).

Tabela 1. Modelos alometricos para estimativa da biomassa seca acima do solo $(\mathrm{kg})$ de florestas tropicais. Modelos de regressão de biomassa podem incluir diâmetro DBH (em cm), altura total H (em metros) e a densidade específica da madeira " $\rho$ " ( $\left(\mathrm{em} \mathrm{g} \mathrm{cm}^{3}\right)$.

$\begin{array}{llllllll}\text { Reference } & \text { Allometric model (AGB) } & \alpha & \beta_{1} & \beta_{2} & \beta_{3} & \mathbf{R}^{2} & \text { DBH range }\end{array}$

Allometric Model with 1 variable - DBH

\begin{tabular}{|c|c|c|c|c|c|c|c|}
\hline Chambers et al. (2001) & $=\exp \left(\alpha+\beta_{1} \ln (\mathrm{DBH})+\beta_{2}(\ln (\mathrm{DBH}))^{2}-\beta_{3}(\ln (\mathrm{DBH}))^{3}\right)$ & -0.37 & 0.333 & 0.933 & -0.1220 & 0.973 & $5-130$ \\
\hline Burger (2005) & $=\exp \left(\alpha+\beta_{1} \ln (\mathrm{DBase})\right)$ & -6.80067 & 3.77738 & - & - & -0.915 & $12.5-27.9 *$ \\
\hline Tiepolo et al. (2002) & $=\alpha+\beta_{1}(\mathrm{DBH})+\beta_{2}(\mathrm{DBH})^{2}$ & 21.297 & -6.953 & 0.740 & - & 0.910 & $4-116$ \\
\hline \multicolumn{8}{|c|}{ Allometric Model with 2 variables - DBH and wood density or DBH and Height } \\
\hline Chave et al., (2005)a** & $\left.\left.=\rho X \exp \left(\alpha+\beta_{1} \ln (\mathrm{DBH})+\beta_{2} \ln (\mathrm{DBH})\right)^{2}-\beta_{3} \ln (\mathrm{DBH})\right)^{3}\right)$ & -1.499 & 2.1481 & 0.207 & -0.0281 & 0.996 & $5-156$ \\
\hline Scatena et al. (1993) & $=\exp \left(\alpha+\beta_{1}\left(\ln (\mathrm{DBH})^{2} \mathrm{X} \mathrm{H}\right)\right)$ & -3.282 & 0.95 & - & - & 0.947 & $2.5-57$ \\
\hline
\end{tabular}

Allometric Model with 3 variables - DBH, wood density, height

Chave et al., (2005)b* $=\rho X \exp \left(\alpha+\ln \left(\rho \mathrm{X} \mathrm{DBH}^{2 *} \mathrm{H}\right)\right.$

$-2.977$

-
$-\quad 0.989 \quad 5-156$

*Base diameter; **These models refer to the moist tropical forests.

*Diâmetro da base; **Estes modelos se referem ao modelo de floresta tropical úmida.
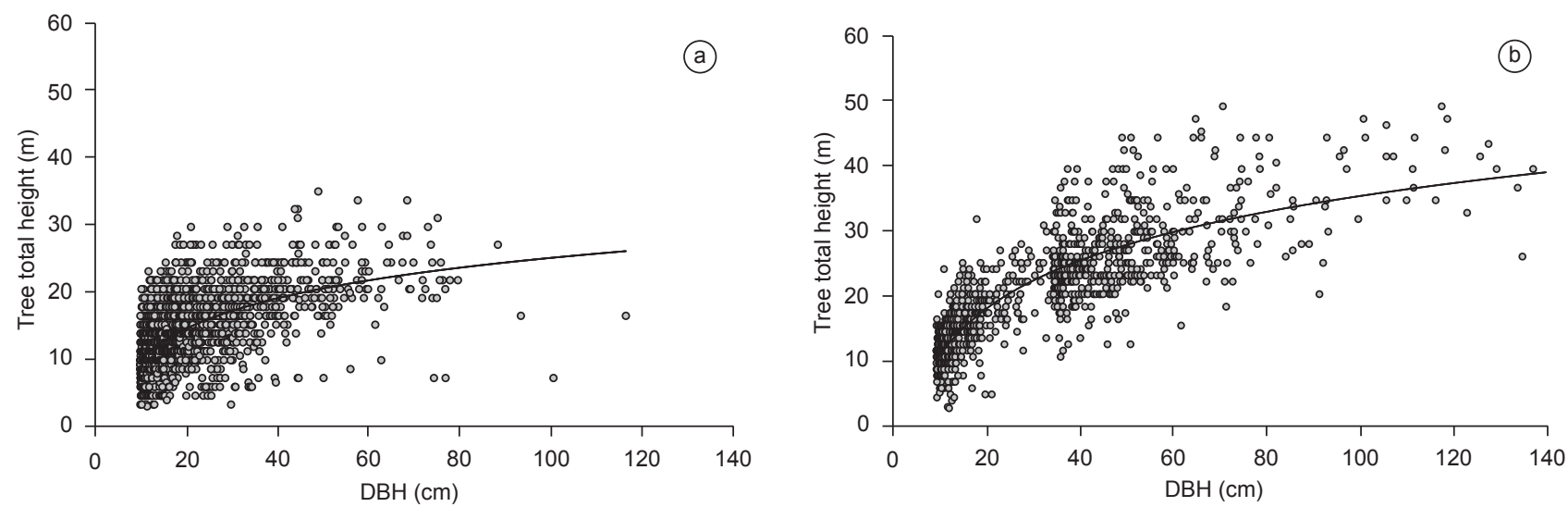

Figure 1. Relation between DBH and tree height at a) Mata Atlântica, and b) tropical forest in the western Amazon. Data from a) BIOTA Gradient Funtional project, and b) Vieira et al. (2004). *In order to produce a preliminary correction for tree heights in the Mata Atlântica, we selected a stratified random sample of 80 trees $(\mathrm{DBH}>5 \mathrm{~cm})$ and measured tree height using either an extensible fiberglass rod graduated in $\mathrm{cm}$, or a laser range finder with an internal clinometer (Laser Ranger Finder, Impulse-200LR, Laser Technology Inc., Englewood, Colorado). The relation between measured height and the visually estimated height is shown in the Figure 3a.

Figura 1. Relação entre DAP (diâmetro à altura do peito) e altura em florestas de a) Mata Atlântica e da b) Amazônia ocidental. Dados oriundo do a) Projeto BIOTA "Gradiente Funcional, e b) Vieira et al. (2004). *Para realizar uma correção preliminar da altura das arvores da Mata Atlântica, nós selecionamos aleatoriamente uma amostra estratificada de 80 árvores (DAP $>5 \mathrm{~cm}$ ) e medimos a altura com o uso de uma régua telescópica graduada (em $\mathrm{cm}$ ) de fibra de vidro, ou com um clinomêtro a laser (Laser Ranger Finder, Impulse 200LR, Laser Technology Inc., Englewood, Colorado). A relação entre a altura medida e a altura estimada visualmente é mostrada na Figura 3a. 
Along with tree height, wood density should also be considered in AGB estimates. Baker et al. (2004a) demonstrated that wood density explained 20 to $30 \%$ of the AGB variation across Amazonian forest sites. The spatial patterns of wood density and tree mass distribution may vary because of biological responses to environmental conditions such as wind and drought. High wood density has been correlated with the increase of the resistance in cell wall of xylem, which reduces cavitation risk due to strong tensions during periods of droughts (Hacke et al. 2001, Muller-Landau 2004, Chave et al. 2006).

Wood density differs among species as well as among individuals from the same species as a result of tree age and edaphic conditions (Baker et al. 2004a, Muller-Landau 2004). Moreover, variations in wood density occur along the trunk (Williamson 1984, Higuchi et al. 1998, Baker et al. 2004a, Muller-Landau 2004). In spite of the high variability, the variation in wood density in tropical rain forest within genera is still less than the wood density between genera (Baker et al. 2004 a, Chave et al. 2006, Slik 2006). Studies of forest biomass have relied on this result using mean values of wood density for genera when no species-specific measurements of wood density were available (Baker et al. 2004a, Magcale-Macandog 2004).

\section{Application to the Atlantic Forest}

We compared four general allometric models based on data from forests in Puerto Rico (Scatena et al. 1993), the central Amazon (Chambers et al., 2001) and throughout the tropics (Chave et al. 2005), and the site specific model for Atlantic Forest developed in a forest located in the Southeast of Brazil, proposed by Tiepolo et al. (2002) that include trees in the same DBH range that in your plots (Table 1). The Burger (2005) model was not used for the AGB estimative because the available survey data do not include values for basal tree diameter. Tree mass versus DBH for five models are compared in Figure 2. The model of Chambers et al. (2001) estimated greater mass for trees with DBH up to $100 \mathrm{~cm}$ at which point there is an inflection point in the model. On the other hand the models proposed by Scatena et al. (1993) and Tiepolo et al. (2002) estimated lower tree mass values than other models from 5 to $\sim 130 \mathrm{~cm} \mathrm{DBH}$.

The allometric models described above were used to estimate the AGB using data from four permanent submontane Atlantic Forest plots (1 ha each) of the BIOTA Gradiente Funcional project. In this area, tree density $\left(>4.8 \mathrm{~cm}\right.$ DBH) is $1493.5 \pm 182.4 \mathrm{stem} \mathrm{ha}^{-1}$. The mean wood density for this area is $0.603 \mathrm{~g} \mathrm{~cm}^{-3}$, calculated from literature values (Lacerda 2001, Chave et. al. 2006). Original height data for this area was collected by visual estimation. While we are currently re-measuring tree heights in the plot, for illustration we have used a relation between height and DBH from a sub-set of the data for height calculation in those models requiring height as an independent variable (Figure 3b).

We observed considerable variation among estimated plot level AGB (Figure 4). The equation developed for the Central Amazon based on DBH alone (Chambers et al. 2001) and the pan-tropical model based on wood density and DBH (Chave et al. 2005, model a) both give higher biomass estimates compared to the model from similar submontane Atlantic Forest (Tiepolo et al. 2002). In contrast, the AGB values obtained using a pan-tropical model that employs wood density, DBH and height (Chave et al. 2005, model b) result in a very similar estimate to the site-specific model of Tiepolo et al. (2002) and with biomass values measured by Burger (2005) and Tiepolo et al. (2002) for two other areas in the Southeast Atlantic Forest. The model of Scatena et al. (1993) developed for Puerto Rican submontane forests that suffer frequent hurricanes give the lowest biomass compared to all of the other models.

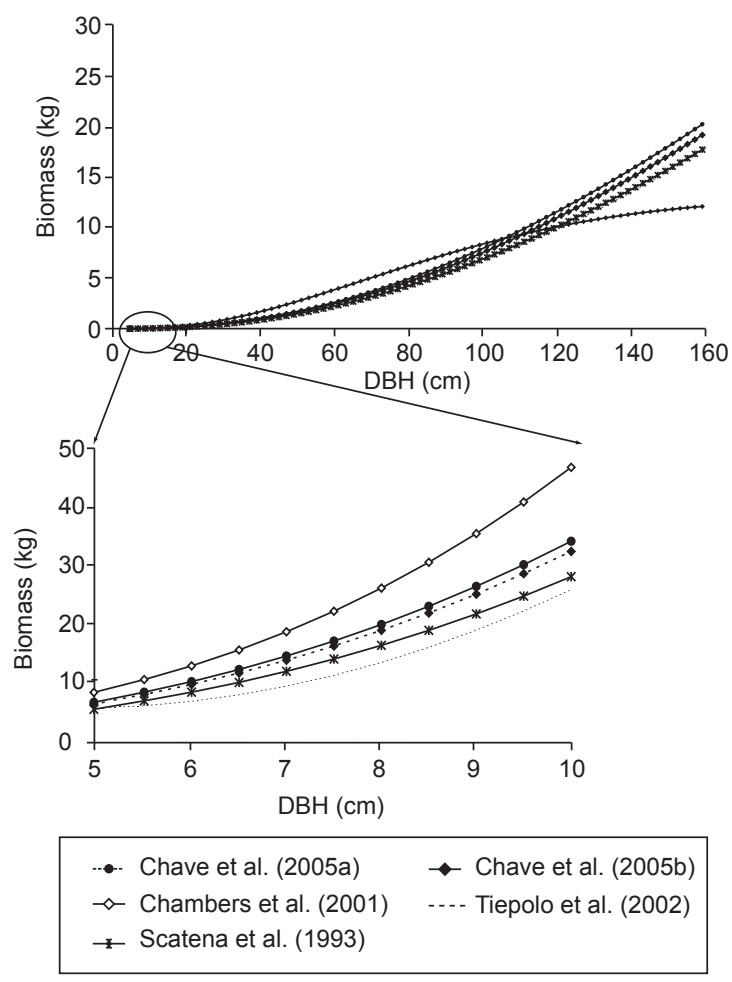

Figure 2. AGB estimation curves for trees with $\mathrm{DBH}>5 \mathrm{~cm}$, using different allometric models. The models that include height as an independent variable estimated height according to the following equation: Height $=\exp ((\ln (\mathrm{AGB} *)+2.557) / 0.94) / 0.616 /((\mathrm{DBH}) 2)$, where AGB is the biomass estimated according to Chave et al. (2005).

Figura 2. Curvas de AGB estimada para árvores com $\mathrm{DBH}>5 \mathrm{~cm}$, utilizando diferentes modelos alométricos. Nos modelos que incluem altura como variável independente, a mesma foi estimada conforme equação abaixo: Altura $=\exp \left(\left(\ln \left(\mathrm{AGB}^{*}\right)+2.557\right) / 0.94\right) / 0.616 /((\mathrm{DBH}) 2)$, onde AGB é a biomassa viva acima do solo estimada de acordo com modelo proposto por Chave et al. (2005).

\section{Other Woody and Non-Woody Components of AGB}

The AGB distribution among woody and non-woody components for tropical forests is poorly known (Sarmiento et al. 2005). The nonwoody components such as tree ferns, epiphytes and bamboos and minor woody components such as palms and lianas can contribute significantly to the AGB of tropical forests and can be responsible for part of the structural variability observed among them (Sarmiento et al. 2005). However, allometric models to estimate the AGB for these life forms are still scarce (Table 2). Although separately they represent a small fraction of total biomass, when evaluated as a group, lianas, palms, tree ferns, bamboo and epiphytes can respond for more than $10 \%$ of the AGB in the Atlantic Forest areas. For example: palms usually do not represent more than 5\% of the AGB, but can reach $10 \%$ or more in some tropical forests (de Castilho et al. 2006); epiphytes commonly represents less than $2 \%$ of AGB (Hofstede et al. 1993, Hsu et al. 2002, Nadkarni et al. 2004). Even though there are no bamboo biomass quantification for the Atlantic Forest, in forests where bamboo is dominant, as open Amazonian forest, bamboo biomass represented no more than $5 \%$ of the total AGB (Torezan \& Silveira, 2000).

After trees, lianas can be one of the most abundant life forms in many tropical forests (Putz 1984, Gerwing et al. 2006, Schnitzer 
Table 2. Allometric models to estimate dry aboveground biomass $(\mathrm{Kg})$ for palms, tree ferns and lianas in tropical forests. Biomass regression models may include trunk diameter DBH (in cm) and total tree height H (in m) and wood specific gravity " $\rho$ " (in $\mathrm{g} . \mathrm{cm}^{3}$ ).

Tabela 2. Modelos alométricos para estimativa da biomassa seca acima do solo $(\mathrm{kg})$ para palmeiras, fetos arborecentes e cipós em floresta tropical. $\left.\mathrm{cm}^{3}\right)$. Modelos de regressão de biomassa podem incluir diâmetro DBH $(\mathrm{em} \mathrm{cm})$, altura total H (em metros) e a densidade específica da madeira " $\rho$ " (em g.cm $\left.{ }^{3}\right)$.

\begin{tabular}{|c|c|c|c|c|c|c|c|}
\hline Life-form & Reference & Allometric model (AGB) & $\alpha$ & $\beta_{1}$ & $\beta_{2}$ & $\mathbf{R}^{2}$ & $\begin{array}{c}\text { DBH }(\mathrm{cm}) \text { and } \\
\text { H }(\mathrm{m}) \text { range }\end{array}$ \\
\hline \multirow[t]{6}{*}{ Palms } & \multicolumn{7}{|c|}{ Allometric Model with 1 variable - DBH or Height } \\
\hline & Tiepolo et al. (2002) & $=\alpha+\beta_{1} *($ Height $)$ & 0.3999 & 7.907 & - & 0.750 & $1-33$ \\
\hline & Brown et al. (2005) & $=\alpha+\left(\beta_{1}\left(\mathrm{DBH}^{0.5}\right) * \ln (\mathrm{DBH})\right)$ & 6.6666 & 12.826 & - & & \\
\hline & Hughes et al. (1999) & $=\exp \left(\left(\left(\alpha+\beta_{1} \ln \left(\mathrm{DBH}^{2}\right)\right) * \beta_{2}\right) / 10^{3}\right.$ & 5.7236 & 0.9285 & 1.05001 & 0.820 & - \\
\hline & \multicolumn{7}{|c|}{ Allometric Model with 2 variables - DBH and Height } \\
\hline & Saldarriaga et al. (1988) & $=\exp \left(\alpha+\beta_{1} \ln \left(1 /(\mathrm{DBH})^{2}\right)+\beta_{2} \ln (\right.$ Height $\left.)\right)$ & -6.3789 & -0.877 & 2.151 & 0.890 & - \\
\hline \multirow[t]{2}{*}{ Tree fern } & \multicolumn{7}{|c|}{ Allometric Model with 1 variable - DBH } \\
\hline & Tiepolo et al. (2002) & $=\alpha /\left(1-\beta_{1} \exp -\beta^{2 * \text { Height }}\right)$ & -4266348 & 2792284 & 0.313677 & 0.880 & $1-8$ \\
\hline \multirow[t]{4}{*}{ Lianas } & \multicolumn{7}{|c|}{ Allometric Model with 1 variable - Diameter } \\
\hline & Gehring et al. (2004) & $=\exp \left(\alpha+\beta_{1}(\ln (\mathrm{D}))\right.$ & 7.114 & 2.276 & & 0.945 & $\begin{array}{l}0.1-13.8(\mathrm{Db}) \\
0.2-48(\mathrm{H})\end{array}$ \\
\hline & Schnitzer et al. (2006) & $=\exp \left(\alpha+\beta_{1}(\ln (\mathrm{D}))\right.$ & -1.484 & 2.657 & & 0.694 & $1-23$ \\
\hline & Gerwing et al. (2000) & $=\exp \left(\alpha+\beta_{1}(\ln (\mathrm{D}))\right.$ & 0.07 & 2.17 & & 0.950 & $1-13.5$ \\
\hline
\end{tabular}
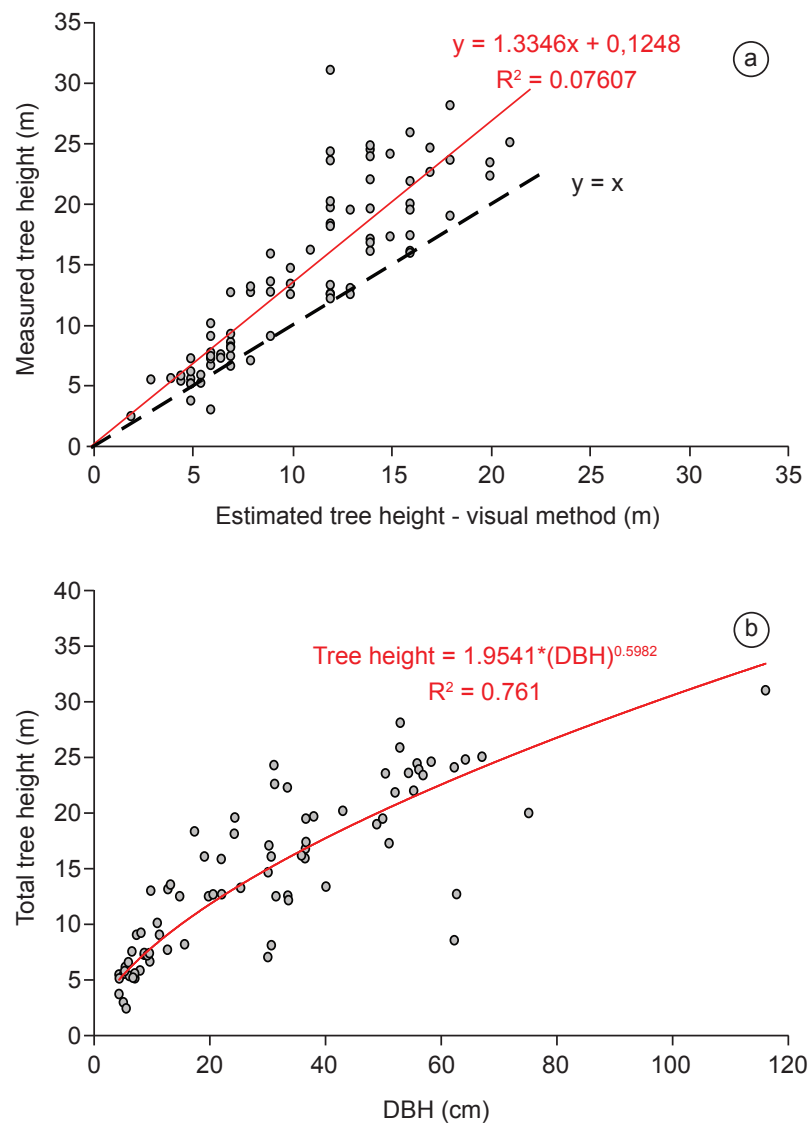

Figure 3. a) Visual estimated tree height vs. measured tree height. b) Relationship between measured tree height and DBH for the Atlantic forest trees.

Figura 3. a) Altura das árvores estimada visualmente comparada com a altura medida. b) Relação entre a altura medida e o DBH de árvores da Mata Atlântica.

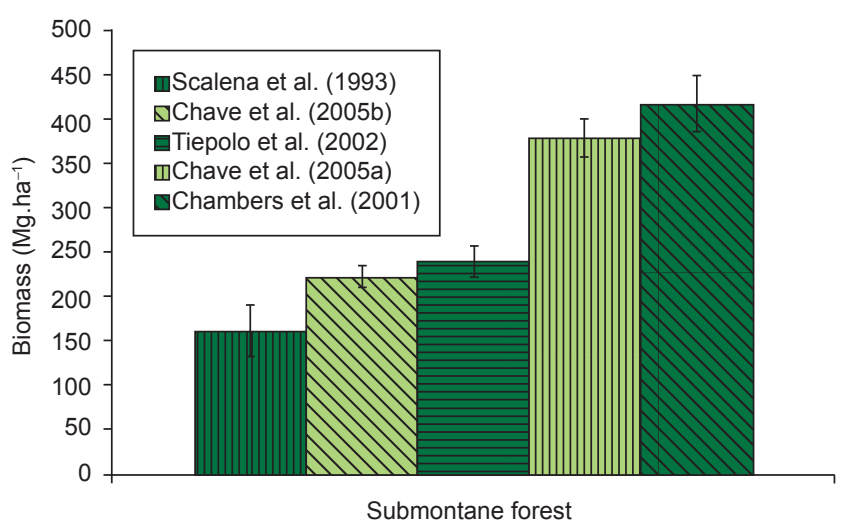

Figure 4. AGB for submontane Mata Atlântica plots. Error bars represent standard deviation. The biomass was estimated according models with one (DBH), two (DBH and height) or three (DBH, height and wood density) variables. The tree height was estimated using $\mathrm{H}=1.9541 \times \mathrm{DBH}^{0.5982}$ (Figure 3b)

Figura 4. AGB de uma floresta ombrófila densa submontana de Mata Atlântica. A barra de erro representa intervalo de confiança de 95\%. A biomassa foi estimada a partir de modelos com uma (DBH), duas (DBH e altura) ou três (DBH, altura e densidade da madeira) variáveis. A altura das árvores foi estimada a partir da equação: Altura $=1.9541 \times \mathrm{DBH}^{0.5982}$ (Figura 3b)

et al. 2006) but in terms of AGB they typically represent no more than $2-5 \%$ of the total (Gerhing et al. 2004).

\section{Final Consideration}

The use of allometric models for estimation of above ground biomass in tropical forests is essential for the study of carbon storage and exchange. Unfortunately, not all areas have well developed allometric equations. Destructive studies necessary to make new equations are costly, labor intensive, and may be difficult to accomplish 
in conservation areas. To select one or other of the available models in the literature to estimate AGB we should take into account what is the main question to be answered and the ease with which it is possible to measure the independent variables in the model. Models that present more accurate estimates should be preferred. However, more simple models (those with one independent variable, usually DBH) can be used when the focus is monitoring the annual increment of tree growth. In the other hand, because lianas, bamboos, palms, tree ferns and epiphytes are also important components in the Atlantic Forest, we recommend the quantification of them in both of cases.

Observations in the Atlantic Forest suggest that, since this biome differ along the coast (North to South) and we do not have a specific allometric model for each one of the different sites, pan-tropical relations can be confidently used to estimate tree biomass across biomes as long as tree diameter (DBH), height, and wood density are accounted for in the model (e.g. Chave et al. 2005, model b).

\section{Acknowledgements}

The workshop was supported by FAPESP (project $n^{\circ}$ 03/12595-7), CAPES, Cnpq, IB/UNICAMP and CENA/USP. We gratefully acknowledge the support of the "Parque Estadual da Serra do MarNúcleo Picinguaba" and to BIOTA/FAPESP program.

\section{References}

ABDALA, G.C., CALDAS, L.S., HARIDASAN, M. \& EITEN, G. 1998 Above and belowground organic matter and root: shoot ratio in a cerrado in Central Brazil. Brazilian J Ecol 2(1):11-13.

ARAÚJO,T.M., HIGUCHI, N. \& CARVALHO, J.A. 1999. Comparison of formulae for biomass content determination in a tropical rain forest site in the state of Pará, Brazil. Forest Ecol Manag., 117(1-3):43-52.

BAKER, T.R., PHILLIPS, O.L., MALHI, Y., ALMEIDA, S., ARROYO, L., DI FIORE, A., ERWIN, T., HIGUCHI, N., KILLEEN, T.J., LAURANCE, S.G., LAURANCE, W.F., LEWIS, S.L., LLOYD, J., MONTEAGUDO, A., NEILL, D.A., PATINO, S., PITMAN, N.C.A., SILVA, J.N.M. \& VASQUEZ MARTINEZ, R. 2004a Variation in wood density determines spatial patterns in Amazonian forest biomass. Global Change Biol. 10:545-562

BAKER, T.R., PHILLIPS, O.L., MALHI, Y., ALMEIDA, S., ARROYO, L., DI FIORE, A., ERWIN, T., HIGUCHI, N., KILLEEN, T.J., LAURANCE, S.G., LAURANCE, W.F., LEWIS, S.L., MONTEAGUDO, A., NEILL, D.A., VARGAS, P.N., PITMAN, N.C.A., SILVA, J.N.M. \& VASQUEZ MARTINEZ, R. 2004b. Increasing biomass in Amazonian forest plots. Philos T Roy Soc B 359(1443):353-365.

BETTS, R.A. 2006. Forcings and feedbacks by land ecosystem changes on climate change. Journal de Physique IV 139(1):119-142

BROWN, S., GILLESPIE, A.J.R. \& LUGO, A.E. 1989. Biomass estimation methods for tropical forest with applications to forest inventory data. Forest Sci. 35(4):881-902

BROWN, S. 1997. Estimating Biomass and Biomass Change of Tropical Forests: a Primer (FAO Forestry Paper-134), FAO, United Nations, Rome.

BURGER, D. 2005. Modelos alométricos para a estimativa da fitomassa de Mata Atlântica na Serra do Mar, SP. Tese de Doutorado, Universidade de São Paulo, São Paulo.

CHAMBERS, J.Q., SANTOS, J, RIBEIRO, R.J. \& HIGUCHI, N. 2001. Tree damage, allometric relationships, and above-ground net primary production in central Amazon Forest. Forest Ecol. Manag. 152(1-3): 73-84.

CHAVE, J., ANDALO, C., BROWN, S., CAIRNS, M., CHAMBERS, J.C., EAMUS, D., FÖLSTER, H., FROMARD, F., HIGUCHI, N., KIRA, T., LESCURE, J., NELSON, B.W., OGAWA, H., PUIG, H., RIÉRA, B. \& YAMAKURA, T. 2005. Tree allometry and improved estimation of carbon stocks and balance in tropical forests. Oecologia 145:87-99.

CHAVE, J., MULLER-LANDAU, H.C., BAKER, T.R., EASDALE, T.A., TER STEEGE, H. \& WEBB, C.O. 2006. Regional and phylogenetic variation of wood density across 2456 neotropical tree species. Ecol Appl. 16(6):2356-2367

COLE, T.C. \& EWEL, J.J. 2006. Allometric equations for four valuable tropical tree species. Forest Ecol. Manag. 229(1-3):351-360.

CURTIS, R.O. 1967. Height-diameter and height-diameter-age equations for second-growth Douglas-fir. Forest Sci. 13(4):365-375.

DAWKINS, H.C. 1961. Estimating total volume of some Caribbean trees. Caribbean Forester 22(1):62-63.

DEAN, W. 1995. With Broadax and Firebrand - The Destruction of the Brazilian Atlantic Forest. University of California Press, Berkeley

CASTILHO, C.V., MAGNUSSON, W.E., ARAUJO, R.N.O., LUIZÂO, R.C.C., LIMA, A.P., HIGUCHI, N. 2006. Variation in aboveground tree live biomass in a central Amazonian Forest: Effects of soil and topography. Forest Ecol. Manag. 234(1-3):85-96.

DELITTI, W.B.C, MEGURO, M. \& PAUSAS, J. 2006 Biomass and mineralmass estimates in a cerrado ecosystem. Revista Brasileira de Botânica 29(4):531-540.

DOMINGOS, M., KLUMPP, A. \& KLUMPP, G. 1998. Air pollution impact on the Atlantic forest the Cubatão region, SP, Brazil. Ciência e Cultura 50(4):230-236

FEELEY, K.J., WRIGHT, S.J., SUPARDI, M.N., KASSIM, A.R., \& DAVIES, S.J. 2007 Decelerating growth in tropical forest trees. Ecol. Lett. 10(6):461-469.

FUJIMOTO, T., KITA, K., UCHIYAMA, K., KUROMARU, M., AKUTSU, H. \& ODA, K. 2006 Age trends in the genetic parameters of wood density and the relationship with growth rates in hybrid larch (Larix gmelinii var. japonica L. kaempferi ) F1. J For Res-Jpn 11(3):157-163

GERHING, C., PARK, S. \& DENICH, M. 2004. Liana allometric biomass equations for Amazonian primary and secondary forest. Forest Ecol. Manag. 195(1-2):69-83.

GERWING, J.J. \& FARIAS, D.L. 2000. Integrating liana abundance and forest stature into an estimate of aboveground biomass for an eastern Amazonian forest. J Trop. Ecol. 16(3):327-336.

GERWING, J.J., SCHNITZER, S.A., BURNHAM, R.A., BONGERS, F., CHAVE, J., DEWALT, S.J., EWANGO, C.E.N., FOSTER, R., KENFACK, D., MARTINEZ-RAMOZ, M., PARREN, M., PARTHASARATHY, N., PEREZ-SALICRUP, D.R., PUTZ, F.E. \& THOMAS, D.W. 2006. A standard protocol for censusing lianas. Biotropica 39(2):256-261

HACKE, U.G., SPERRY, J.S., POCKMAN, W.T., DAVIS, S.D. \& MCCULLOH, K.A. 2001. Trends in wood density and structure are linked to prevention of xylem implosion by negative pressure. Oecologia 126(4):457-461

HIGUCHI, N., SANTOS, J., RIBEIRO, R.J., MINETTE L. \& BIOT, Y. 1998. Biomassa da parte aérea da vegetação da floresta tropical úmida de terrafirme da Amazônia brasileira. Acta Amazonica 28(2):153-166

HIROTA, M.M. 2003. Monitoring the Brazilian Atlantic Forest Cover. In The Atlantic Forest of South America: Biodiversity Status, Threats, and Outlook. (C. Galindo-Leal and I. Gusmão Camara). Island Press, Washington, DC. pp. 60-65.

HOFSTEDE, R.G.M., WOLF, J.H. \& BENZING, D.H. 1993. Epiphyte biomass and nutrient status of a Colombian upper montane rain forest Selbyana 14:37-45.

HOLDRIDGE, L.R., GRENKE, W.C., HATHEWAY, W.H., LIANG, T. \& TOSI JR., J.A. 1971. Forest environment in tropical life zones: a pilot. Pergamon, Oxford

HOUGHTON, R.A. \& HACKLER, J.L. 2006. Emissions of carbon from land use change in sub-Saharan Africa. J Geophys Res-Biogeosciences 111(G2): Art. No. G02003

HSU, C.C., HORNG, F.W. \& KUO, C.M. 2002. Epiphyte biomass and nutrient capital of a moist subtropical forest in north-eastern Taiwan. J Trop. Ecol. 18:659-670.

HULTINE, K.R., KOEPKE, D.F., POCKMAN, W.T., FRAVOLINI, A., SPERRY, J.S. \& WILLIAMS, D.G. 2005. Influence of soil texture on hydraulic properties and water relations of a dominant warm-desert phreatophyte. Tree Physiol 26(3):313-323 
IBGE. 1992. Manual técnico da vegetação brasileira. Manuais técnicos em geociências. Instituto Brasileiro de Geografia e Estatística, Rio de Janeiro.

JACKSON, R.B., BANNER, F.L., JOBBÁGY, E.G, POCKMAN, W.T. \& WALL, D.H. 2001. Ecosystem carbon loss with woody plant invasion of grasslands. Nature 418(6898):623-626

JANDL, R, LINDNER, M., VESTERDAL, L., BAUWENS, B., BARITZ, R., HAGEDORN, F., JOHNSON, D.W., MINKKINEN, K. \& BYRNE, K.A. 2007. How strongly can forest management influence soil carbon sequestration? Geoderma 137(3-4):253-268

JOLY, C.A., AIDAR, M.P.M., KLINK, C.A., MCGRATH, D.G., MOREIRA, A.G., MOUTINHO, P., NEPSTAD, D.C., OLIVEIRA, A.A., POTT, A., RODAL, M.J.N. \& SAMPAIO, E.V.S.B. 1999. Evolution of the Brazilian phytogeography classification systems: implications for biodiversity conservation. Ciência e Cultura 51:331-348.

KETTERINGS, Q.M., COE, R.NOORDWIJK, M. van, AMBAGAU, Y. \& PALM, C.A. 2001. Reducing uncertainty in the use of allometric biomass equations for predicting above-ground tree biomass in mixed secondary forests. Forest Ecol Manag 146(1):199-209.

KING, D.A., DAVIS, S.J., SUPARDI, M.N.N. \& TAN, S. 2005.Tree growth is related to light interception and wood density in two mixed dipterocarp forests of Malaysia. Funct Ecol 19(3):445-453

KING, D.A. 1996. Allometry and life history of tropical trees. J Trop Ecol 12(1):25-44.

LACERDA, M.S. 2001. Composição florística e estrutura da comunidade arbórea num gradiente altitudinal da Mata Atlântica. Tese de Doutorado, Instituto de Biologia, Universidade Estadual de Campinas, Campinas.

LEITÃO FILHO, H.F. 1993. Ecologia da Mata Atlântica em Cubatão. Ed. UNESP/UNICAMP, São Paulo e Campinas.

LEWIS, S.L., PHILLIPS, O.L., BAKER, T.R., LLOYD, J., MALHI, Y., ALMEIDA, S., HIGUCHI, N., LAURANCE, W.F., NEILL, D.A., SILVA, J.N.M., TERBORGH, J., LEZAMA, A.T., MARTINEZ, R.V., BROWN, S., CHAVE, J., KUEBLER. C., VARGAS, P.N. \& VINCETI, B. 2004. Concerted changes in tropical forest structure and dynamics: evidence from 50 South American long-term plots. Philosophical Philos T Roy Soc B 359 (1443):421-436.

LOETSCH, F. \& HALLER, K.E. 1973 Forest Inventory. BLV Verlagsgesellschaft Muenchen, Bern, Wien.

MACHADO, S.A. \& FIGUEIREDO, A. 2003. Dendrometria. UFPR, Curitiba. $309 \mathrm{p}$.

MAGCALE-MACANDOG, D.B. 2004. Comparative evaluation of different approaches to estimate aboveground biomass and biomass density of tropical forests in Southeast Asia: a review. Philipp Agric Sci 87: 61-75.

MALHI, Y., BALDOCCHI, D.D. \& JARVIS, P.G. 1999. The carbon balance of tropical, temperate and boreal forests. Plant Cell Environ 22(6): 715-740.

MORAES, R.M., DELITTI, W.B.C. \& STRUFFALDI-DE-VUONO, Y. 1999. Litterfall and nutrient return in two Brazilian tropical forests. Rev Bras Bot 22(1):9-16.

MORELLATO, L.P.C. \& HADDAD, C.F.B. 2000. Introduction: The Brazilian Atlantic forest. Biotropica 32(4b):786-792

MULLER-LANDAU, H.C. 2004. Interspecific and inter-site variation in wood specific gravity of tropical trees. Biotropica 36 (1):20-32

MYERS, N., MITTERMEIER, R.A., MITTERMEIER, C.G., FONSECA, G.A.B. \& KENT, J. 2000. Biodiversity hotspots for conservation priorities. Nature 403(1):852-858.

NADKARNI, N.M., SCHAEFER, D., MATELSON, T.J. \& SOLANO, R. 2004. Biomass and nutrient pools canopy and terrestrial components in a primary and secondary montane cloud forest, Costa Rica. Forest Ecol Manag 198(1-3):223-236.

NASCIMENTO, H.E.M. \& LAURANCE, W.F. 2002. Total aboveground biomass in central Amazonian rainforests: a landscape-scale study. Forest Ecol Manag 168(1-3):311-321
OLIVEIRA FILHO, A. \& FONTES, M.A. 2000. Patterns of floristic differentiation among Atlantic Forests in south-eastern Brazil, and the influence of climate. Biotropica 32(4b):793-810.

OVERMAN, J.P., WITTE, H.J. \& SALDARRIAGA, J.G. 1994. Evaluation of regression models for aboveground biomass determination in Amazon rainforest. J Trop Ecol 10(2):207-218.

PHILLIPS, O.L. \& GENTRY, A.H. 1994. Increasing turnover through time in tropical forests. Science 263(5149):954-958.

PHILLIPS, O.L., MALHI, Y., HIGUCHI, N., LAURANCE, W.F., NUNEZ, P.V., VASQUEZ, R.M., LAURANCE, S.G., FERREIRA, L.V., STERN, M., BROWN,S. \& GRACE, J. 1998. Changes in the carbon balance of tropical forests: Evidence from long-term plots. Science 282(5388): 439-442.

PHILLIPS, O.L., MARTINEZ, R.V., ARROYO, L., BAKER, T.R., KILLEEN, T., LEWIS, S.L., MALHI, Y., MENDOZA, A.M., NEILL, D., VARGAS, P.N., ALEXIADES, M., CERON, C., DI FIORE, A., ERWIN, T., JARDIM, A., PALACIOS, W., SALDIAS, M. \& VINCETI, B. 2002. Increasing dominance of large lianas in Amazonian forests. Nature 418(6899):770-774.

PILI, R., ANFODILLO, T. \& CARRER, M. 2006. Towards a functional and simplified allometry for estimating forest. Forest Ecol Manag 237(1-3): 583-593

PUTZ, F.E. 1984 The natural history of lianas on Barro Colorado Island, Panama. J Ecol 65(6):1713-1734.

RAMANKUTTY, N., GIBBS, H.K., ACHARD, F., DEFRIESS, R., FOLEY, J.A. \& HOUGHTON, R.A. 2007 Challenges to estimating carbon emissions from tropical deforestation. Global Change Biol 13(1):51-66

RICE, A.H., PYLE, E.H., SALESKA, S.R., HUTYRA, L., PALACE, M., KELLER, M., DE CAMARGO, P.B., PORTILHO, K., MARQUES, D.F. \& WOFSY, S.C. 2004.Carbon balance and vegetation dynamics in an old-growth Amazonian forest. Ecol Appl 14(4):S55-S71

SALDARRIAGA, J.G., WEST, D.C., THARP, M.L. \& UHL, C.1988. Longterm chronosequence of forest sucession in the upper Rio Negro of Colombia and Venezuela. J Ecol 76(4):938-958.

SANTILLI, M., MOUTINHO, P., SCHWARTZMAN, S., NEPSTAD, D., CURRAN, L. \& NOBRE, C. 2005. Tropical deforestation and the Kyoto Protocol: An editorial essay. Climatic Change 71(3):267-276.

SARMIENTO, G., PINILLOS, M. \& GARAY, I. 2005. Biomass variability in tropical American lowland rainforest. Ecotropicos 18(1):1-20.

SCATENA, F.N., SILVER, W., SICCAMA, T., JOHNSON, A. \& SÁNCHEZ, M.J. 1993. Biomass and nutrient content of the Bisley Experimental Watersheds, Luquillo Experimental Forest, Puerto Rico, before and after Hurricane Hugo, 1989. Biotropica 25(1):15-27.

SCHNITZER, S.A., DEWALT, S.J. \& CHAVE, J. 2006. Censusing and measuring lianas: a quantitative comparison of the common methods. Biotropica 38(5):581-591.

SLIK, J.W.F. 2006. Estimating species-specific wood density from the genus average in Indonesian trees. J Trop Ecol 22:481-482.

STERCK, F.J., BONGERS, F. \& NEWBERY, D.M. 2001. Tree architecture in a Bornean lowland rain forest: intraspecific and interspecific patters. Plant Ecol 153(1-2):279-292.

SWAINE, M.D. \& WHITMORE, T.C. 1988. On the definition of ecological species groups in tropical rain forests. Vegetatio 75(1-2):81-86

TIEPOLO, G., CALMON, M. \& FERETTI, A.R. 2002. Measuring and Monitoring Carbon Stocks at the Guaraqueçaba Climate Action Project, Paraná, Brazil. In: International Symposium on Forest Carbon Sequestration and Monitoring. Extension Serie Taiwan Forestry Research Institute 153:98-115.

TOREZAN, J.M.D. 1995. Estudo da sucessão secundária, na floresta ombrófila densa submontana, em áreas anteriormente cultivadas pelo sistema de "coivara", em Iporanga - S.P. Dissertação de mestrado, Universidade Federal do Paraná, Curitiba.

TOREZAN, J.M.D. \& SILVEIRA, M. 2000. The biomass of bamboo (Guadua weberbaueri Pilger) in open forest of the Southwestern Amazon. Ecotropica 6(1):71-76. 
VENKATESWARAN, R. \& PARTHASARATHY, N. 2005. Tree population changes in a tropical dry evergreen forest of south India over a decade (1992-2002). Biodivers Conserv 14(6):1335-1344.

VIEIRA, S., DE CAMARGO, P.B., SELHORST, D., DA SILVA, R., HUTYRA, L., CHAMBERS, J.Q., BROWN, I.F., HIGUCHI, N., DOS SANTOS, J., WOFSY, S.C., TRUMBORE, S.E. \& MARTINELLI, L.A 2004. Forest structure and carbon dynamics in Amazonian tropical rain forest. Oecologia 140(3):468-479.

VILLELA, D.M., NASCIMENTO, M.T., ARAGÃO, L.E.O.C. \& GAMA, D.M. 2006. Effect of selective logging on forest structure and nutrient cycling in a seasonally dry Brazilian Atlantic forest. J Biogeogr 33(3): 506-516
WILLIAMSON, G.B. 1984. Gradients in wood specific gravity of trees. B Torrey Bot Club 111(1):468-479

WIRTH, C., SCHUMACHER, J. \& SCHULZE, E.D. 2004. Generic biomass functions for Norway spruce in Central Europe. A meta-analysis approach toward prediction and uncertainty estimation. Tree Physiol 24(2):121-139

Data Received 20/09/07 Revised 31/01/08 Accepted 01/04/08 